\title{
PENYULUHAN TENTANG STUNTING (KERDIL) PUSKESMAS HARAPAN RAYA PEKANBARU
}

\author{
Riza Febrianti ${ }^{1)}$ Intan Widya Sari ${ }^{2)}$ \\ STIKes Hang Tuah Pekanbaru ${ }^{1)}$ \\ Email : rizafebrianti77@yahoo.com
}

\begin{abstract}
In general, malnutrition is caused by insufficient food intake and infectious diseases. There are two main groups of nutrients, namely macro nutrients and micro nutrients (Admin, 2008). Macro nutrients are nutrients that provide energy for the body and are needed for growth, including in These include carbohydrates, proteins, and fats. Meanwhile, micronutrients are nutrients needed to carry out other body functions, for example in producing red blood cells, the body needs iron, including vitamins and minerals.
\end{abstract}

Keywords : Stunting, Malnutrition

\section{ABSTRAK}

Gizi buruk disebabkan karena asupan makanan yang tidak mencukupi dan penyakit infeksi. Terdapat dua kelompok utama zat gizi yaitu zat gizi makro dan zat gizi mikro (Admin, 2008).

Zat gizi makro merupakan zat gizi yang menyediakan energi bagi tubuh dan diperlukandalam pertumbuhan, termasuk di dalamnya adalah karbohidrat, protein, dan lem ak. Sedangkan zat gizi mikro merupakan zat gizi yang diperlukan untuk menjalankan fungsi tubuh lainnya, misalnya dalam memproduksi sel darah merah, tubuh memerlukan zat besi.Termasuk di dalamnya adalah vitamin dan mineral.

Kata Kunci : Stunting, Gizi Buruk

\section{PENDAHULUAN}

Di negara berkembang, kesakitan dan kematian pada anak balita banyakdipengaruhi oleh status gizi (Supariasa, 2001). Status gizi balita perludipertahankan dalam status gizi baik, dengan cara memberikan makanan bergizi seimbang yang sangat penting untuk pertumbuhan (Paath, 2004).
Perkembangan masalah gizi di Indonesia semakin kompleks saat ini,salah satunya yaitu mengenai persoalan Balita Pendek ( stunting). Stunting dapatdi diagnosis melalui indeks antropometri tinggi badan menurut umur yang mencerminkan pertumbuhan linier yang dicapai pada pra dan pasca persalinan dengan indikasi kekura ngan gizi jangka panjang, akibat dari gizi yang tidak memadai. 
Stunting merupakan pertumbuhan linear yang gagal untuk mencapai potensi genetik sebagai akibat dari pola makan yang buruk dan penyakit infeksi (ACC/SCN, 2000).

Secara umum gizi buruk disebabkan karena asupan makanan yang tidak mencukupi dan penyakit infeksi. Terdapat dua kelompok utama zat gizi yaitu zat gizi makro dan zat gizi mikro (Admin, 2008). Zat gizi makro merupakan zat gizi yang menyediakan energi bagi tubuh dan diperlukan dalam pertumbuhan, termasuk di dalamn ya adalah karbohidrat, protein, dan lema k. Sedangkan zat gizi mikro merupakan zat gizi yang diperlukan untuk menjalankan fungsi tubuh lainnya, misalnya dalam memproduksi sel darah merah, tubuh memerlukan zat besi. Termasuk di dalamnya adalah vitamin dan mineral.

Di Indonesia, diperkirakan 7,8 juta anak mengalami stunting, data

ini berdasarkan laporan yang dikeluarka $\mathrm{n}$ oleh UNICEF dan memposisikanIndon esia masuk ke dalam 5 besar negara dengan jumlah anak yang mengalami stunting tinggi (UNICEF, 2007). Hasil Riskesdas 2010, secara nasional prevalensi kependekan pada anak umur 2-5 tahun di Indonesia adalah 35,6\%yang terdiri dari 15,1\% sangat pendek dan $20 \%$ pendek.

\section{METODE PENERAPAN}

Metode pengabdian masyarakat ini dilaksanakan dalam bentuk Penyuluhan dan Metode demonstrasi dengan menerapkan langsung setelah diberikan penyuluhan

\section{HASIL DAN PEMBAHASAN}

\section{A. HASIL PELAKSANAAN}

KeStunting (Kerdil) telah
dilaksanakagiatan penyuluhan dan
pelatihan n pada tanggal 16 januari 2020
sebanyak 20 orang di Puskesmas
Harapan raya Pekanbaru. Berdasrkan
wawancara, tanya jawab danpengamatan
langsung selama kegiatan pengabdian
masyarakat ini memberikan hasil
berikut:
1. Tenaga kesehatan
Berdasarkan hasil pelaksanaan
penyuluhan Stunting di puskesmas
Harapan Raya

2. Peserta/ibu-ibu
a. ibu-ibu memahami teknik penyuluhan
b. ibu-ibu memahami tentang materi penyuluhan Stunting yang disampaikan oleh pemateri.

\section{B. Pembahasan}

Kegiatan penyuluhan stunting yang dilaksakan di puskesmas Harapan Raya berjalan dengan baik dan sesuai 
rencana. Hal ini terbukti antusiasme para peserta saat mengikuti jalanya kegiatan. Para peserta penyuluhan benar-benar memperhatikan dan mendengarkan dengan baik penyuluhan yang disampaikan
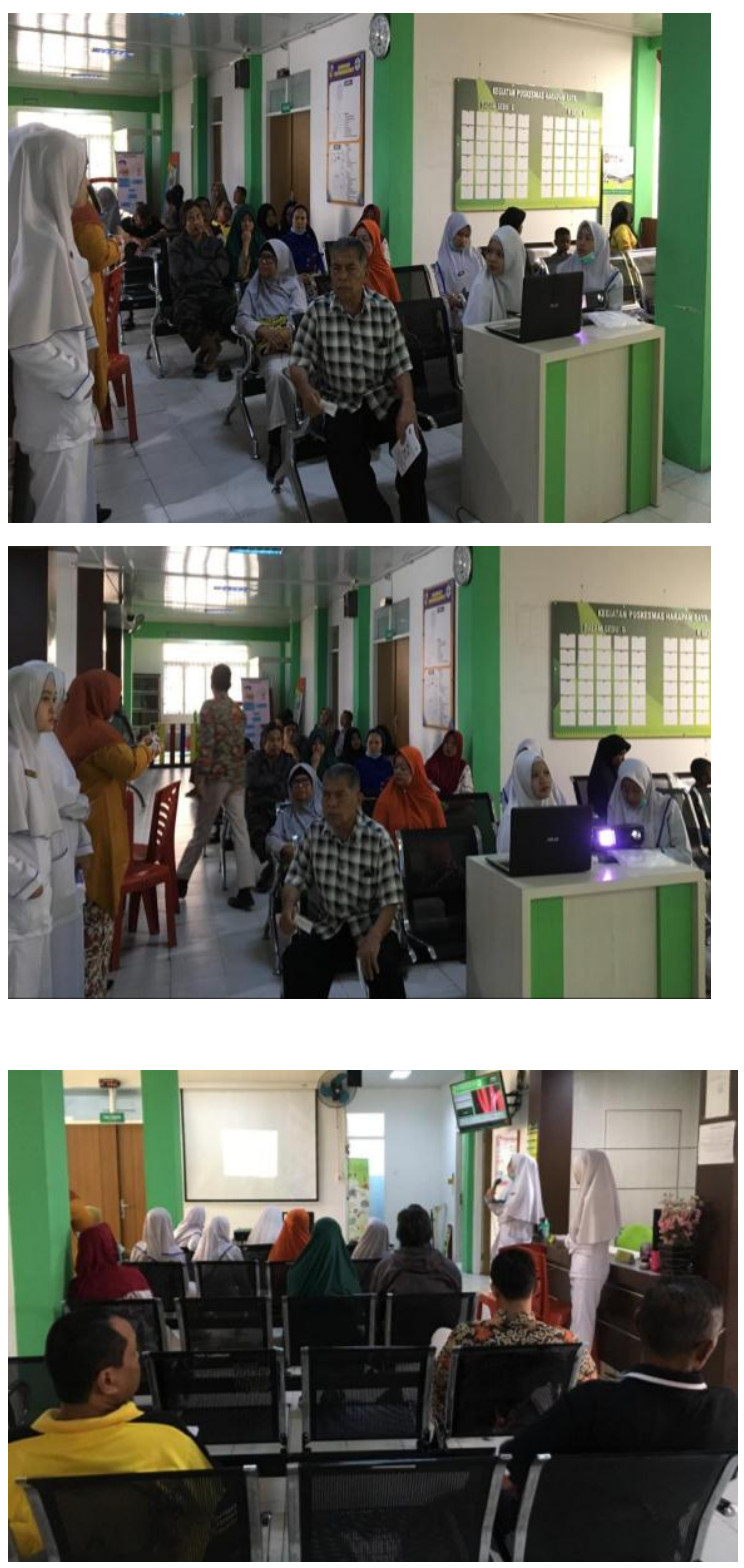

\section{KESIMPULAN}

Indonesia memiliki berbagai macam masalah dalam perkembangangizi seperti Stuntingatau balita pendek, pemberian ASI, dan berbagaikendala lainnya yang mengancam keselamatan dan kesehatan anak usia bayi dan balita. Untuk mengatasi hal tersebut perlu adanya upaya pencegahan dari pemerintah maupun masyarakat seperti pemberian penyuluhan akan pentingnya gizi dan sosialisasi mengenai dampak negative kurang gizi bagi masyarakat

\section{DAFTAR PUSTAKA}

http://repository.unimus.ac.id/2000/3/b ab\%202.pdf

http://eprints.poltekkesjogja.ac.id/1134/

4/4.\%20Chapter\%202.pdf 